\title{
Monocyte Chemotactic Protein-1 (MCP-1), -2, and -3 Are Chemotactic for Human T Lymphocytes
}

\author{
Dennis D. Taub, * Paul Proost, " William J. Murphy, ” Miriam Anver, ${ }^{5}$ Dan L. Longo," Jo Van Damme," \\ and Joost J. Oppenheim" \\ *Clinical Services Program, and ${ }^{\ddagger}$ Biological Carcinogenesis and Development Program, and ${ }^{\S}$ Pathology Histotechnology Laboratory, \\ Program Resources, Inc., DynCorp and "The Laboratory of Molecular Immunoregulation and the Office of the Associate Director, \\ Biological Response Modifiers Program, National Cancer Institute-Frederick Cancer Research and Development Center, Frederick, \\ Maryland 21702; 'Laboratory of Molecular Immunology, Rega Institute, University of Leuven, Belgium
}

\begin{abstract}
Monocyte chemotactic protein (MCP)-1, -2, and -3 all have been shown to induce monocyte/macrophage migration in vitro and MCP-1, also known as MCAF, chemoattracts basophils and mast cells. We report here that natural MCP1 as well as synthetic preparations of MCP-2 and MCP-3 stimulate significant in vitro chemotaxis of human peripheral blood T lymphocytes. This MCP-induced migration was dose-dependent and directional, but not chemokinetic. Phenotypic analysis of the $T$ cell population responsive to MCP1, MCP-2, and MCP-3 demonstrates that both $\mathrm{CD4}^{+}$and $\mathrm{CD8}^{+} \mathrm{T}$ cells migrated in response to these chemokines. Similar results were observed using human $\mathrm{CD4}^{+}$and $\mathrm{CD8}^{+}$ $T$ cell clones. Neutralizing antisera to MCAF or MCP-2 abrogated T cell migration in response to MCP-1 and MCP2 , respectively, but not to RANTES. Subcutaneous administration of purified MCP-1 into the hind flanks of SCID mice engrafted with human peripheral blood lymphocytes (PBL) induced significant human $\mathrm{CD3}^{+} \mathrm{T}$ cell infiltration into the site of injection at $4 \mathrm{~h}$. These results demonstrate that MCP1, MCP-2, and MCP-3 are inflammatory mediators that specifically stimulate the directional migration of $T$ cells as well as monocytes and may play an important role in immune cell recruitment into sites of antigenic challenge. $(J$. Clin. Invest. 1995. 95:1370-1376.) Key words: MCP-1 • MCP-2 • MCP-3 - T lymphocytes $\cdot$ chemokines
\end{abstract}

\section{Introduction}

The local accumulation of inflammatory cells appears to be mediated by the local production and secretion of a family of $8-10-\mathrm{kD}$ chemotactic cytokines (called chemokines) by nonleukocytic and leukocytic cell types (1). All of the chemokines have been found to induce directional migration of various cell

Address correspondence to Dr. Dennis D. Taub, Clinical Services Program, PRI/DynCorp, Frederick Cancer Research and Development Center-National Cancer Institute, Bldg 560, Rm 11-23, Frederick, MD 21702-1201. FAX: 301-846-6022.

Received for publication 11 July 1994 and in revised form 8 December 1994.

The Journal of Clinical Investigation, Inc.

Volume 95, March 1995, 1370-1376 types, including neutrophils, monocytes, $\mathrm{T}$ lymphocytes, basophils, eosinophils, or fibroblasts (2-4). Many of the $\alpha$ chemokine subfamily members with a C-X-C structure such as interleukin-8 (IL-8), GRO, ENA-78, neutrophil attracting protein-2 (NAP-2), interferon-inducible protein-10 (IP-10) and granulocyte chemotactic protein-2 (GCP-2) have been shown to chemoattract and activate neutrophils. In contrast, all of the $\beta$ chemokines characterized by a C-C structure including macrophage inflammatory protein-1 $\alpha$ (MIP-1 $\alpha$ ), MIP-1 $\beta$, RANTES, macrophage chemotactic protein-1 (MCP-1), MCP2 , and MCP-3 chemoattract and activate monocytes. Previous studies have also demonstrated that the $\beta$ chemokines MIP- $1 \alpha$, MIP-1 $\beta$, RANTES and the $\alpha$ chemokines IL- 8 and IP-10 also induce the directional migration of human $\mathrm{T}$ cells and $\mathrm{T}$ cell subsets (5-10). A more recent report has described the ability of purified human MCP-1 to induce $\mathrm{T}$ cell migration through an endothelial cell barrier (11).

The human MCP-1 cDNA encodes a 99-amino acid residue precursor protein with a 23-residue signal peptide that is cleaved to generate the 76-residue mature protein (12). In one publication, MCP-1 has been reported to activate monocytes or macrophages to arrest growth of some tumor target cells and therefore has also been called monocyte chemotactic and activating factor $(\mathrm{MCAF})^{1}$ (13). Recently, two additional monocyte chemoattractants MCP-2 and MCP-3, showing 62 and $71 \%$ homology respectively with MCP-1 have been biochemically isolated, identified, and synthesized $(14,15)$. The chemotactic potency for monocytes was comparable for all three MCPs. However, MCP-1 induced a higher number of cells to migrate than MCP3 and MCP-2 which were less effective. Intradermal injection of each of these chemokines in rabbits has resulted in selective monocyte recruitment in vivo within $18 \mathrm{~h}(14,15)$.

Apart from its chemotactic activity on monocytes, MCAF/ MCP-1 can stimulate the following activities in monocytes: to be cytostatic for some human and mouse tumor cell lines; to increase intracellular calcium levels; and to induce the release of superoxide anions and lysosomal enzymes from monocytes in vitro $(2,16)$. While none of the MCP proteins have been shown to have any effect on neutrophil migration, MCAF/MCP1 has also been shown to chemoattract and induce histamine release by basophils and mast cells (17-19). Although the recombinant human MCAF has multiple biological activities,

1. Abbreviations used in this paper: MCAF, monocyte chemotactic and activating factor; NK, natural killer. 
there has been a report that purified natural MCP-1 has higher biological affinity and is a more potent monocyte chemoattractant (20).

Since a number of the other $\beta$ chemokines attract $\mathrm{T}$ cells as well as monocytes, we have tested natural MCP-1 and synthetic MCP-2 and MCP-3 in chemotaxis assays for their ability to induced the migration of purified human peripheral blood $\mathrm{T}$ cells.

Despite the fact that earlier preparations of recombinant MCAF were not chemotactic for $T$ cells, all of the naturally derived MCP proteins induce $\mathrm{T}$ cell migration in vitro. The $\mathrm{T}$ cell response to these chemokines is both dose-dependent and similar in potency to RANTES, MIP- $1 \alpha$, and MIP- $1 \beta$. The effect of these three homologous chemokines on $\mathrm{T}$ lymphocytes was evaluated in vitro as well as in vivo.

\section{Methods}

Cells. Peripheral blood mononuclear cells (PBMC) were obtained from normal donors by leukopheresis. The donors had given informed consent. $T$ cells and $T$ cell subsets were purified using a modified procedure using R\&D T cell and T cell subset enrichment columns ( $R \& D$ Systems, Minneapolis, MN). Briefly, PBMC were passaged over Ficoll-Hypaque to remove erythrocytes, granulocytes, and cellular debris. $\mathrm{T}$ cells were isolated following the manufacturer's instructions with the following modification. Viable cells isolated from the $\mathrm{F} / \mathrm{H}$ interface $\left(1 \times 10^{7}\right.$ cells $/ \mathrm{ml}$ ) were subsequently incubated at $4^{\circ} \mathrm{C}$ with $10 \mu \mathrm{g} / \mathrm{ml}$ anti-CD16 antibody for $30 \mathrm{~min}$, and then passaged over an R\&D System $T$ cell enrichment column. Preincubation of PBMCs with anti-CD16 antibody facilitates removal of natural killer (NK) cells from the $\mathrm{T}$ cell preparations. This isolation procedure typically yielded $>94 \% \mathrm{CD}^{+} \mathrm{CD}^{-} 9^{-}$ $\mathrm{CD}^{-} 6^{-} \mathrm{CD}^{-} 6^{-}$lymphocytes. Similarly, $\mathrm{CD} 4^{+}$and $\mathrm{CD} 8^{+} \mathrm{T}$ cell subsets were also isolated using R\&D Systems $T$ cell subset columns following the manufacturer's instructions and typically yielded $>93 \%$ purified $\mathrm{T}$ cell subpopulations. The contaminating cell populations in the $T$ cell and $T$ cell subsets preparations were negative for the CD14, CD16, CD19, and CD56 markers and therefore did not include NK cells, monocytes, or B cells.

The tetanus toxoid-reactive $\mathrm{CD} 4{ }^{+} \mathrm{T}$ cell clone, $2 \mathrm{~B} 1$ and the alloreactive $\mathrm{CD}^{+} \mathrm{T}$ cell clone, $\mathrm{C} 6 \mathrm{~B} 7$ were isolated from the blood of normal consenting donors and were characterized by this laboratory as previously described (5).

Chemokines. Natural human MCP-1 was isolated from cytokinestimulated osteosarcoma cells and purified to homogeneity (21). MCP-2 and MCP-3 were chemically synthesized on a 431A solid-phase peptide synthesizer (Applied Biosystems, Foster City, CA) using Fmoc chemistry. Folding, disulfide bridge formation and purification were as described (21). rhMCAF was expressed in E. coli and fresh batches were purchased from Pepro Tech, Inc. (Rocky Hill, NJ) and R\&D Systems (Minneapolis, MN). rhMIP-1s and rhRANTES were purchased from R\&D Systems (Minneapolis, MN). Antibodies against rhMCAF and synthetic MCP-2 were raised in rabbits (22). Control rabbit antisera to ENA-78 was generously donated by Drs. Steven Kunkel and Robert Sreiter (University of Michigan Medical School, Ann Arbor, MI).

Chemotaxis Assay. T cell migration was quantitated using a modification of the Boyden chamber technique. Briefly, $T$ cells were suspended at $10^{7}$ cells $/ \mathrm{ml}$ in RPMI 1640 plus $0.5 \%$ heat-inactivated hu-AB serum, and were placed in the top wells of a 48-well microchemotaxis chamber. The upper and lower wells were separated by a $5-\mu \mathrm{m}$ pore size polycarbonate filter that separated the cells from the control and experimental samples in the bottom wells. All polycarbonate filters used were coated with fibronectin 1-2 hr before use in the assay (D. Taub, unpublished observation). All responses and filters were assayed in triplicate. The chambers were incubated for $4 \mathrm{~h}$ at $37^{\circ} \mathrm{C}$ in a $5 \% \mathrm{CO}_{2}$ moist atmosphere, and the filters were washed to remove non-migrating $T$ cells from the upper surface. Filters were subsequently fixed in methanol and stained with Diff-Quik, and the numbers of migrating $\mathrm{T}$ cells per high-power field were counted for each well. The results represent the average number of migrating cells per high power field $( \pm S D)$. The statistical significance of these results was determined using an unpaired student's $t$ test.

Mice. C. $b-17$ scid/scid (SCID) mice were obtained from the Animal Production Area (NCI-FCRDC, Frederick, MD). Mice were used at 8 12 wk of age and were kept under specific pathogen-free conditions. The SCID mice were housed in microisolator cages, and all food, water, and bedding were autoclaved before use. SCID mice also received 40 mg trimethoprim and $200 \mathrm{mg}$ of sulfamethoxazole per $320 \mathrm{ml}$ of drinking water.

Transfer of huPBL. All mice received $20 \mu \mathrm{l}$ of $\alpha$ ASGM1 i.p. $1 \mathrm{~d}$ before human cell injection (anti-ASGM1; Wako Chemicals, Dallas, TX), which we previously found to improve human cell engraftment through the abrogation of SCID NK activity (23). HuPBL were obtained from healthy donors in leukopacks. All donors were screened for HIV1 and hepatitis B before donation and signed informed consent forms. The huPBL were then elutriated to remove monocytes and fractions containing $>90 \%$ of lymphocytes were used. The cells were then counted on a Coulter Counter (Coulter Electronics, Hialeah, FL) and 1 $\times 10^{8}$ huPBL were injected i.p. into the SCID recipients. Immediately after huPBL injection, MCP-1 ( $1 \mu \mathrm{g}$ in $0.1 \mathrm{ml}$ HBSS $)$ or $0.1 \mathrm{ml} \mathrm{HBSS}$ were injected s.c. in the SCID mice and were assayed $4 \mathrm{~h}$ after a single injection.

Immunohistochemistry. Skin injection sites and the underlying body wall were embedded in O.C.T. compound tissue medium (Baxter Health Care Corp., Charlotte, N.C.), snap-frozen on dry ice and stored at $-70^{\circ} \mathrm{C}$ until sectioning. Tissues were sectioned on a cryostat at $5 \mu \mathrm{m}$. Before staining, tissue sections were warmed to room temperature, fixed for 10 min in acetone, and rinsed in PBS. The following primary mouse mAb were used: DAKO-CD3, T3-4B5 (normal human blood T lymphocytes); DAKO-CD4, MT310 (helper/inducer T lymphocytes, CD4); DAKO-CD8, and DK25 (suppressor/cytotoxic T lymphocytes, CD8) (Dako Corporation, Carpenteria, CA). Dilutions of antibody were $1: 150,1: 40$, and 1:30 respectively; incubation time was $30 \mathrm{~min}$. The avidin-biotin complex (ABC) method was used with the mouse $A B C$ Vectastain Elite Kit (Vector Laboratories, Burlingame, CA) as the secondary antibody and 3,3' diaminobenzidine as the chromogen. Mayer's hematoxylin was used as a counter-stain. An injection site negative control (mouse Elite kit and no primary antibody) and a positive control (pelleted normal human lymphocytes) were included for each sample run.

\section{Results and Discussion}

Chemotactic effect of purified hMCP-1 and synthetic MCP-2 and $M C P-3$ for resting human T lymphocytes. Purified unstimulated human $\mathrm{T}$ lymphocytes consistently responded to 0.01 to $1 \mathrm{ng} / \mathrm{ml}$ of purified hMCP-1, synthetic hMCP-2 and hMCP-3, and recombinant hRANTES $(P>0.05)$ (Fig. $1 A)$. Higher concentrations $(>10 \mathrm{ng} / \mathrm{ml})$ demonstrated only a modest migratory response on unstimulated $\mathrm{T}$ cells, thus yielding a typical "bell-shaped" curve. In many cases, MCP-3 required concentrations of $1 \mathrm{ng} / \mathrm{ml}$ or above to induce significant $\mathrm{T}$ cell migration. Migratory responses by unstimulated $\mathrm{T}$ cells were also observed using rhRANTES at similar concentrations. In our assay system as with many others (5-11), only a small percentage of the loaded $\mathrm{T}$ cells migrate in response to MCP-1, -2 , and $-3(\sim 2-8 \%$ of the total number of $\mathrm{T}$ cells were MCPresponsive, depending on the donor). Similar percentages of migrating $\mathrm{T}$ cells were also observed in response to the MIP$1 \mathrm{~s}$ and RANTES. Fresh batches of recombinant human $E$. coliderived MCAF/MCP-1 from PeproTech were similar in potency but less efficacious in inducing unstimulated $\mathrm{T}$ cell migra- 

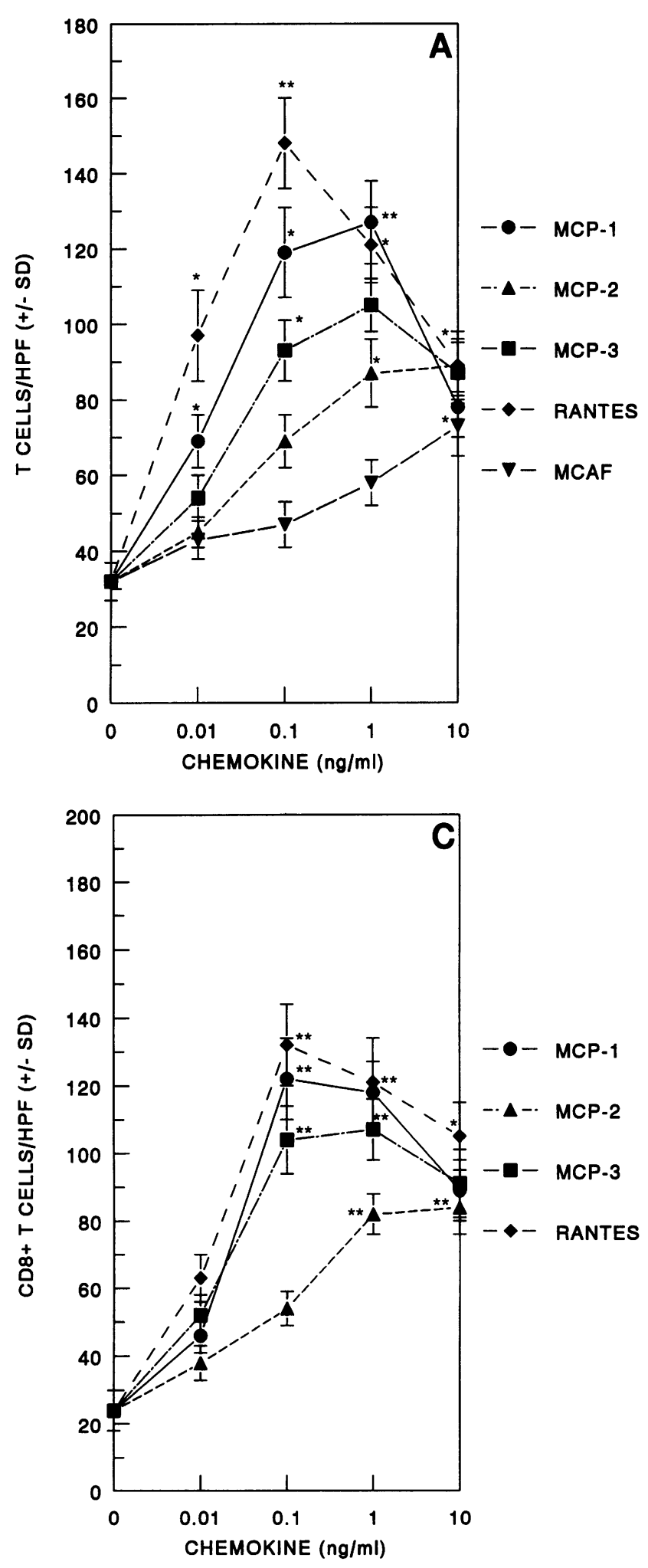

tion compared to similar concentrations of natural MCP-1 (Fig. $1 \mathrm{~A}$ ). These results were very unexpected because previous preparations of rhMCAF/MCP-1 which have the identical sequence as the purified natural MCP-1 were chemotactic for monocytes, basophils, and mast cells, but failed to chemoattract unstimulated or activated $\mathrm{T}$ cells. These earlier preparations of rhMCAF/MCP-1 had about one-half the binding capacity and

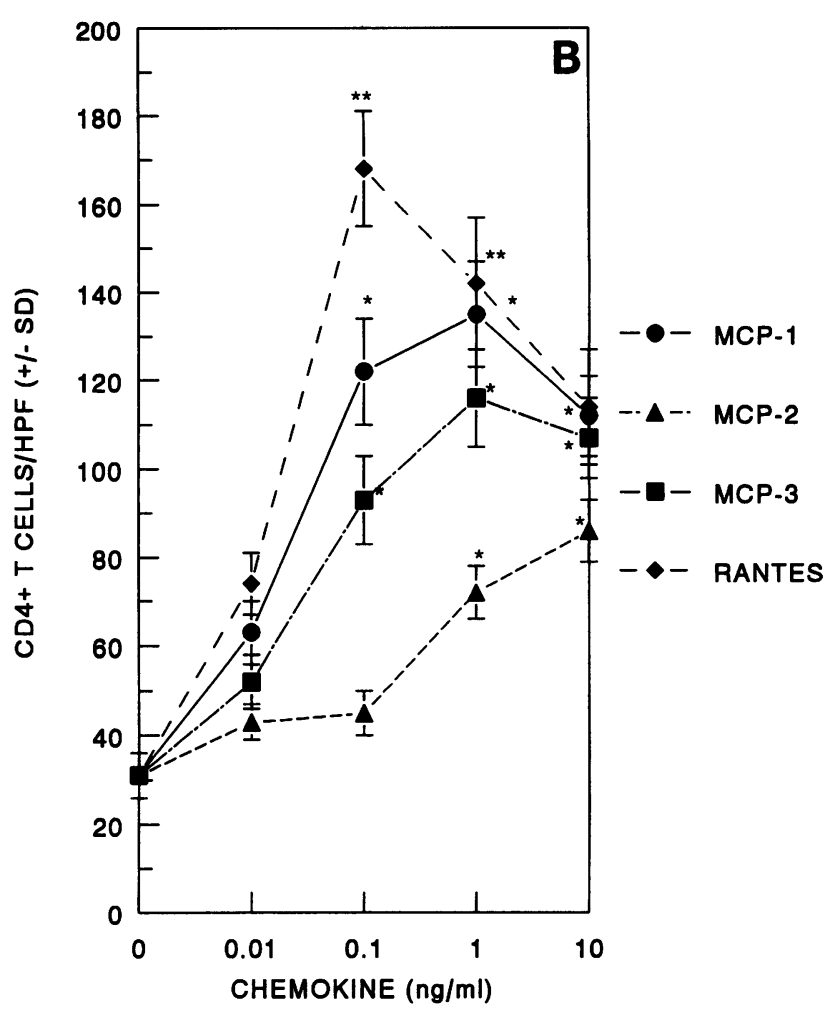

Figure 1. Purified hMCP-1 and synthetic preparations of MCP-2 and MCP-3 are chemotactic for resting human $\mathrm{T}$ lymphocytes and $\mathrm{T}$ lymphocyte subsets on fibronectin-coated filters. Human lymphocytes were isolated as described in Methods and were tested for chemotactic activity in response to various concentrations of MCP-1, $-2,-3$, RANTES, and MCAF in a 48-well microchemotaxis assay. Purified unstimulated T lymphocytes $(A)$ were separated by negative selection into purified $\mathrm{CD}^{+}$ $(B)$ and $\mathrm{CD}^{+}(C) \mathrm{T}$ cell populations (see Methods). Lymphocytes were separated from the chemokine dilutions by a human fibronectin-coated polycarbonate filters. The results are expressed as the mean number of migrating cells per high powered field $( \pm S D)$. This representative experiment has been performed at least six times with different $\mathrm{T}$ cell donors $(n=6)$. Astericks indicate significant $\mathrm{T}$ cell migration. ${ }^{*} P>0.05 ; * *$ $>0.01$.

chemotactic activity for monocytes shown by purified preparations of MCAF/MCP-1 and may have been suboptimal (20). In the present study, a number of the conditions in the assay for $\mathbf{T}$ cell chemotaxis were modified which may account for the improved reactivity of unstimulated $\mathrm{T}$ cells to recombinant MCAF. The T cells were rapidly purified by chromatography at $25^{\circ} \mathrm{C}$. The filters were coated with fibronectin rather than 
Table I. MCP-1 is Chemotactic not Chemokinetic for Human T Cells*

\begin{tabular}{ccccc}
\hline & \multicolumn{4}{c}{ MCP-1 (ng/ml) in upper wells ${ }^{+}$} \\
\cline { 2 - 5 } $\begin{array}{c}\text { Lower wells } \\
\text { MCP-1 (ng/ml) }\end{array}$ & \multicolumn{1}{c}{0} & \multicolumn{1}{c}{0.1} & 1.0 & 10 \\
\hline 0 & $28(3)$ & $35(5)$ & $22(7)$ & $20(5)$ \\
0.1 & $117(11)^{* *}$ & $43(4)$ & $23(8)$ & $25(3)$ \\
1.0 & $89(5)^{* *}$ & $75(4)^{* *}$ & $39(7)$ & $26(5)$ \\
10.0 & $54(3)^{*}$ & $67(5)^{*}$ & $42(6)$ & $29(4)$
\end{tabular}

* Different concentrations of natural MCP-1 were placed in the upper and/or lower wells of the chemotaxis chamber. A fibronectin-coated polycarbonate filter separated the fresh purified $\mathrm{T}$ cells placed in the upper wells from the MCP-1 diutions in the lower wells. The chemotaxis chamber was incubated at $37^{\circ} \mathrm{C}$ for $4 \mathrm{~h}$ in $5 \% \mathrm{CO}_{2}$. After incubation, the filter was removed, scraped, fixed in methanol, stained, and counted on a light microscope. ${ }^{\dagger}$ The results are expressed as the mean number of migrating $T$ cells per high power fields $( \pm S D)$. This experiment has been performed at least three times with different T cell donors $(n=$ 3). $* P<0.05 ; * * P<0.01$.

collagen, because it yields better lymphocyte adherence and migration (data not shown). Checkerboard analysis established that the MCP-1, -2 , and -3 chemokines induce chemotactic rather than chemokinetic migration. Less than $8 \%$ of all MCPinduced $\mathrm{T}$ cell migration was found to be chemokinetic (Table I). These technical improvements have enabled us to detect $\mathrm{T}$ cell chemotactic responses to picogram rather than nanogram concentrations of MCP-1, -2 , and -3 as well as MIP-1 and RANTES chemokines by resting rather than anti-CD3-activated $\mathrm{T}$ cells (5).

The chemoattractant effect of $h M C P-1, h M C P-2$, and hMCP-3 on subsets of $C D 4^{+}$and $C D 8^{+} T$ lymphocytes. Previous studies from several laboratories have revealed that MIP$1 \alpha$ preferentially chemoattracts activated $\mathrm{CD} 8^{+} \mathrm{T}$ cells, while MIP- $1 \beta$ preferentially chemoattracts preactivated $\mathrm{CD} 4^{+} \mathrm{T}$ lymphocytes $(5,8)$. Thus, the selective chemotactic effects of $\mathrm{MCP}-1, \mathrm{MCP}-2$, and $\mathrm{MCP}-3$ on $\mathrm{CD}^{+}{ }^{+}$and $\mathrm{CD} 8{ }^{+} \mathrm{T}$ cells were evaluated. The results (Fig. $1 A-C$ ) show significant migration of $\mathrm{CD}^{+}$and $\mathrm{CD}^{+}{ }^{+} \mathrm{T}$ cells of MCP-1, MCP-2, and MCP-3 as well as RANTES at concentrations of 0.1 and $1 \mathrm{ng} / \mathrm{ml}(P$ $<0.05)$. However, in the same series of experiments, only $\sim 50 \%$ of the $\mathrm{T}$ cell donors exhibited preferential chemotaxis of $\mathrm{CD}^{+}$and $\mathrm{CD} 4^{+} \mathrm{T}$ cell subsets in response to MIP- $1 \alpha$ and MIP- $1 \beta$, respectively. We feel that there is a preferential subset chemotactic effect associated with MIP- $1 \alpha$ and MIP- $1 \beta$; however this effect appears to be donor-dependent and may involve issues of maturation and cellular activation. The ability of MCPs to induce $\mathrm{T}$ cell subset migration was further supported through the use of human $\mathrm{CD}^{+}{ }^{+}$and $\mathrm{CD}^{+} \mathrm{T}$ cell clones (Fig. 2). Both the tetanus-toxoid reactive $\mathrm{CD} 4{ }^{+} \mathrm{T}$ cell clone, $2 \mathrm{~B} 1$, and the alloreactive $\mathrm{CD}^{+} \mathrm{T}$ cell clone, $\mathrm{C} 6 \mathrm{~B} 7$, migrate in response to MCP-1, MCP-2, and MCP-3 as well as the $\beta$ chemokine RANTES. The clones responded to these chemokines at similar dose ranges $(0.01-1 \mathrm{ng} / \mathrm{ml})$ as purified $\mathrm{T}$ cell subpopulations. Of the $\mathrm{T}$ cell clones loaded into the chamber, only $2-12 \%$ of the clones tested migrated in response to the chemokines suggesting that even homogeneous populations will not results in high migrating percentages. In several human $\mathrm{CD}^{+}$and $\mathrm{CD} 8^{+} \mathrm{T}$ cell clone studies, we have also observed preferential
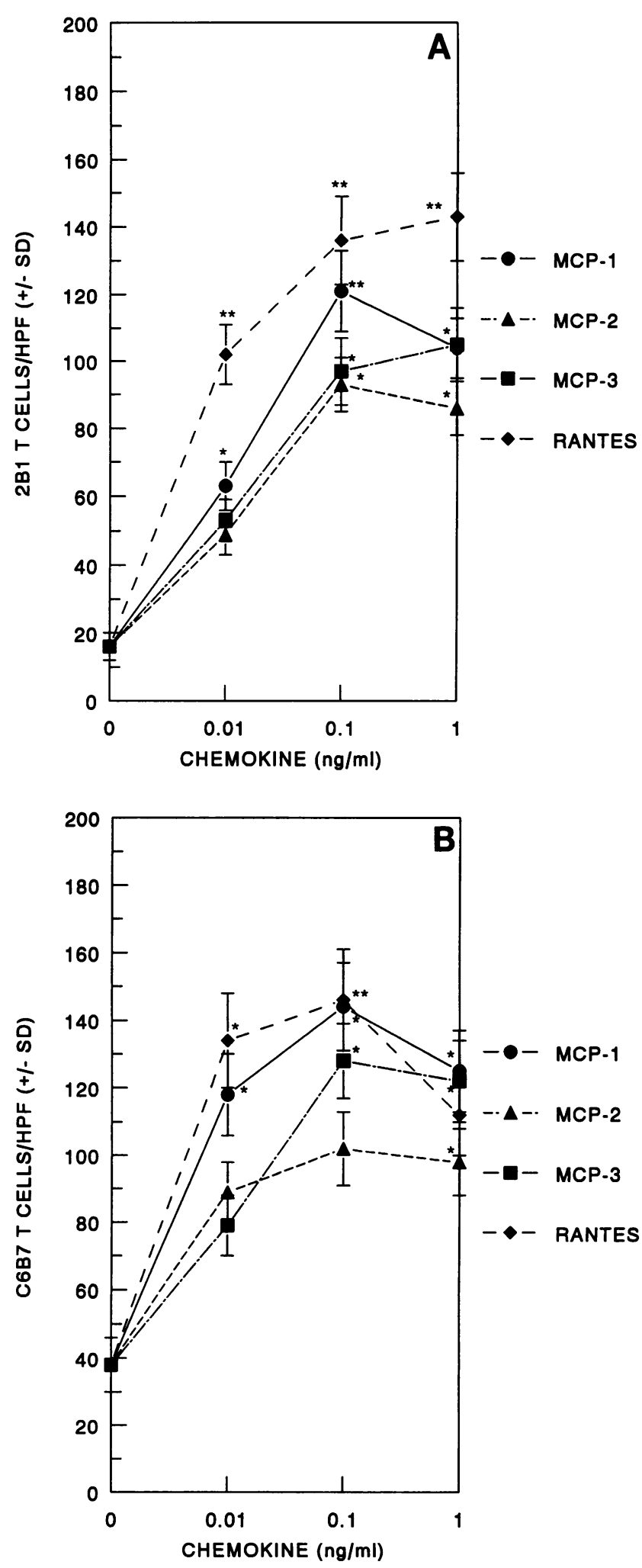

Figure 2. The effect of hMCP-1, hMCP-2, and hMCP-3 on the chemotactic response of $\mathrm{CD}^{+}$and $\mathrm{CD} 8^{+}$human $\mathrm{T}$ cell clones. The tetanus toxoid-reactive $\mathrm{CD}^{+}, 3 \mathrm{E} 12$, and the alloreactive $\mathrm{CD} 8{ }^{+}$clone, $\mathrm{C} 6 \mathrm{~B} 7$, were tested for their ability to migrate in response to various concentrations of chemokine as described in Methods. The results are expressed as the mean number of migrating $T$ cells per high power field $( \pm S D)$. This representative experiment has been performed at least four times $(n=4)$. Astericks indicate significant levels of $\mathrm{T}$ cell migration. ${ }^{*} P$ $>0.05, * * P>0.01$. 


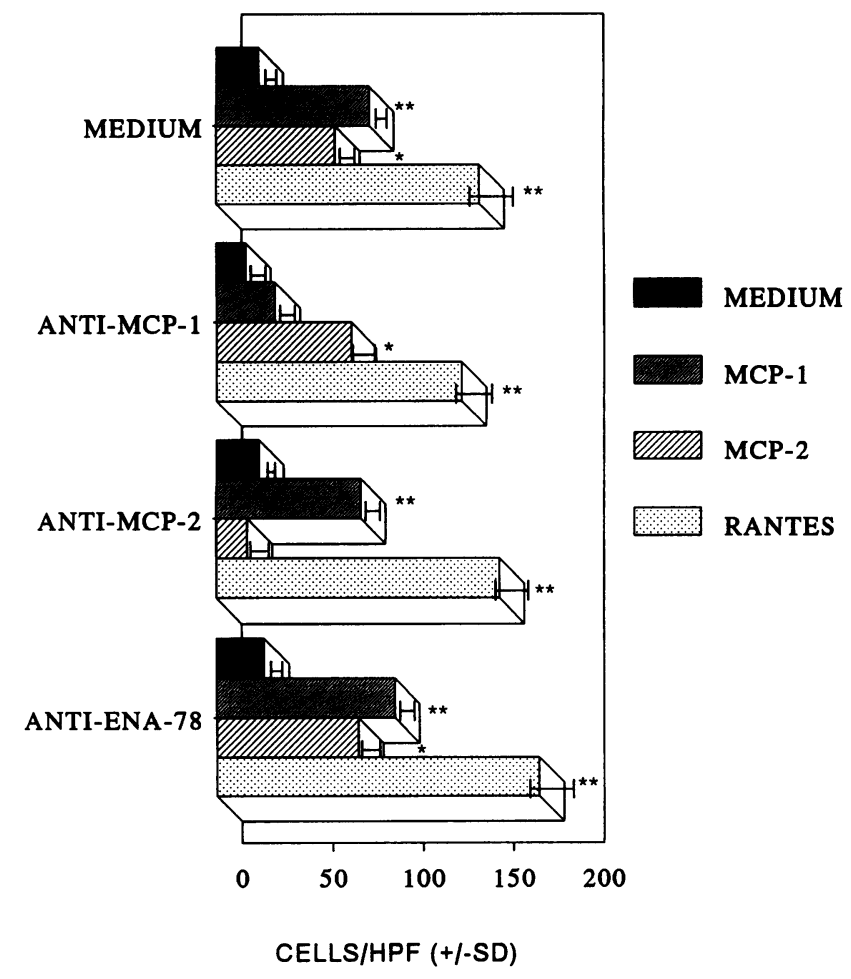

Figure 3. Neutralizing antisera to MCP-1 and MCP-2 inhibits MCP-1and MCP-2-induced T cell migration, respectively. MCP-1, MCP-2, and RANTES at $0.1 \mathrm{ng} / \mathrm{ml}$ were preincubated with a $1 / 100$ dilution of rabbit antisera specific for MCP-1 or MCP- 2 or a control antisera specific for ENA-78 for $30 \mathrm{~min}$ on ice. After incubation, both treated and untreated chemokine preparations were placed in the bottom wells of the microchemotaxis chamber and tested for lymphocyte migration. The results are expressed as the mean number of $\mathrm{T}$ cells per high power field $( \pm$ SD). This representative experiment is quite reproducible and has been performed on three different donors $(n=3)$. Astericks $(*)$ indicate significant changes $(P>0.05)$ between untreated and antibody-treated groups.

migration to MIP-1 $\alpha(\mathrm{CD} 8+)$ and MIP-1 $\beta(\mathrm{CD} 4+)$ in a significant percentage of the clones tested (D. Taub, unpublished observations ). Additional phenotyping is needed to characterize the subset of T cells which selectively respond to MIP- $1 \alpha$ versus MIP-1 $\beta$.

Inhibitory effect of specific antibodies on MCP-1- and $M C P-2-i n d u c e d T$ cell migration. Polyclonal neutralizing rabbit antisera specific for MCP-1 inhibited MCP-1 - but not MCP2 -induced $\mathrm{T}$ cell migration in a 48 -well microchemotaxis assay $(P>0.05)$ (Fig. 3). Similarly, antisera to MCP-2 inhibited MCP-2-mediated T cell migration $(P>0.05)$ while having little to no effect on migration in response to MCP-1. Neither antibody had any significant effect on $\mathrm{T}$ cell chemotaxis in response to RANTES. Control antisera to ENA-78 also failed to inhibit MCP-1 - and MCP-2-induced lymphocyte movement. These experiments show that antibodies specifically inhibit the capacity of MCP-1 and -2 rather than contaminant chemokines to chemoattract unstimulated $\mathrm{T}$ cells.

Effect of purified MCP-1 on human $C D 3^{+} T$ cell accumulation in huPBL-SCID mice in vivo. Since purified MCP-1 was chemotactic for $\mathrm{T}$ cells in vitro, we wanted to evaluate its effects on human $\mathrm{T}$ cell migration in vivo. We examined the effects of purified MCP-1 using a huPBL-SCID model we have developed (23). In this model, huPBL were injected into the peritoneal cavity of SCID mice followed a single subcutaneous injection of either purified MCP-1 ( $1 \mu \mathrm{g})$ or HBSS into the mouse hindflank. $4 \mathrm{~h}$ later, the injection site was biopsied and examined by immunohistology for the presence of human $\mathrm{T}$ cells as determined by anti-CD3 staining. We have previously demonstrated that injections of either HBSS (Fig. $4 \mathrm{~A}$ ) or rhM-CSF (data not shown) does not result in significant human $\mathrm{T}$ cell infiltration after $4 \mathrm{~h}$ (23). However, it should be noted that a small number of murine leukocytes were observed in the histiological sections of the HBSS injection site. Immunohistological analysis revealed that a significant percentage of the infiltrating cells were human $\mathrm{CD}^{+} \mathrm{T}$ cells present in the biopsy area of the huPBLSCID mice receiving one injection of purified MCP-1 (Fig. 4 $B$ ). These results then support the in vitro data indicating that MCP-1 is chemotactic for human T cells both in vitro and in vivo. However, one cannot rule out that the effects of MCP-1 in vivo may also be indirect due to its chemotactic effects on murine macrophages which may then elicit human $\mathrm{T}$ cell chemotaxis as well as possible effects of MCP-1 on the expression of other cytokines and/or adhesion molecules which may mediate these effects.

MCP-1, -2 , and -3 , like RANTES, MIP- $1 \alpha$, and MIP- $1 \beta$, are known to be potent monocyte chemoattractants (2-4). All of these chemokines attract monocytes over similar dose ranges and do not chemoattract neutrophils. The MCP chemokines also demonstrate similar effects on T cell chemotaxis as RANTES and MIP-1 over comparable dose ranges. In addition, similar percentages of human $\mathrm{T}$ cells (between 2 and $8 \%$ ) appear to migrate in response to all the chemokines suggesting that only certain $\mathrm{T}$ cell populations within the bulk preparations have the capacity to respond and/or migrate to chemotactic signals. A recent report by Carr and colleagues have also demonstrated that purified human MCP-1 is capable of eliciting significant T cell migration through an endothelial cell barrier at a dose range of $50-500 \mathrm{ng} / \mathrm{ml}$ with a similar number of $\mathrm{T}$ cells responding (up to $2-3 \%$ of the loaded population) (11). Differences in the dose of $\mathrm{MCP}-1$ required to induce $\mathrm{T}$ cell movement between laboratories may be due to differences in the systems utilized, more specifically a transendothelial migation versus a Boyden

Figure 4. Purified MCP-1 induces human T cell migration into sites of injection into chimeric huPBL-SCID mice. Mice were injected with huPBL i.p. followed by either a s.c injection of HBSS or MCP-1 $(1 \mu \mathrm{g})$. The skin of MCP-1 or HBSS injection sites were frozen in O.C.T. tissue medium (Baxter Health Care Corp., Charlotte, NC) and sections were cut as described in the Materials and Methods. The sections were then stained with anti-CD3 (biotin) followed by anti-mouse Ig peroxidase antibody which results in the brown labeling of CD3 ${ }^{+}$cells. Panel A shows the biopsy area $(40 \times)$ of a SCID mouse receiving huPBL with a single dose of HBSS. No CD ${ }^{+}$cells are detected. Panel B shows the biopsy area (40 $\times$) of a SCID mouse receiving huPBL with a single s.c. injection of MCP-1. Note the infiltration of human $\mathrm{CD}^{+} \mathrm{T}$ cells in the subcutaneous fatty tissues of the skin biopsy (arrow). Arrows indicate areas of human T cell infiltration. This representative experiment was found to be reproducible and has been performed at least three times with purified MCP-1 and/or recombinant MCAF/MCP-1 $(n=3)$. 

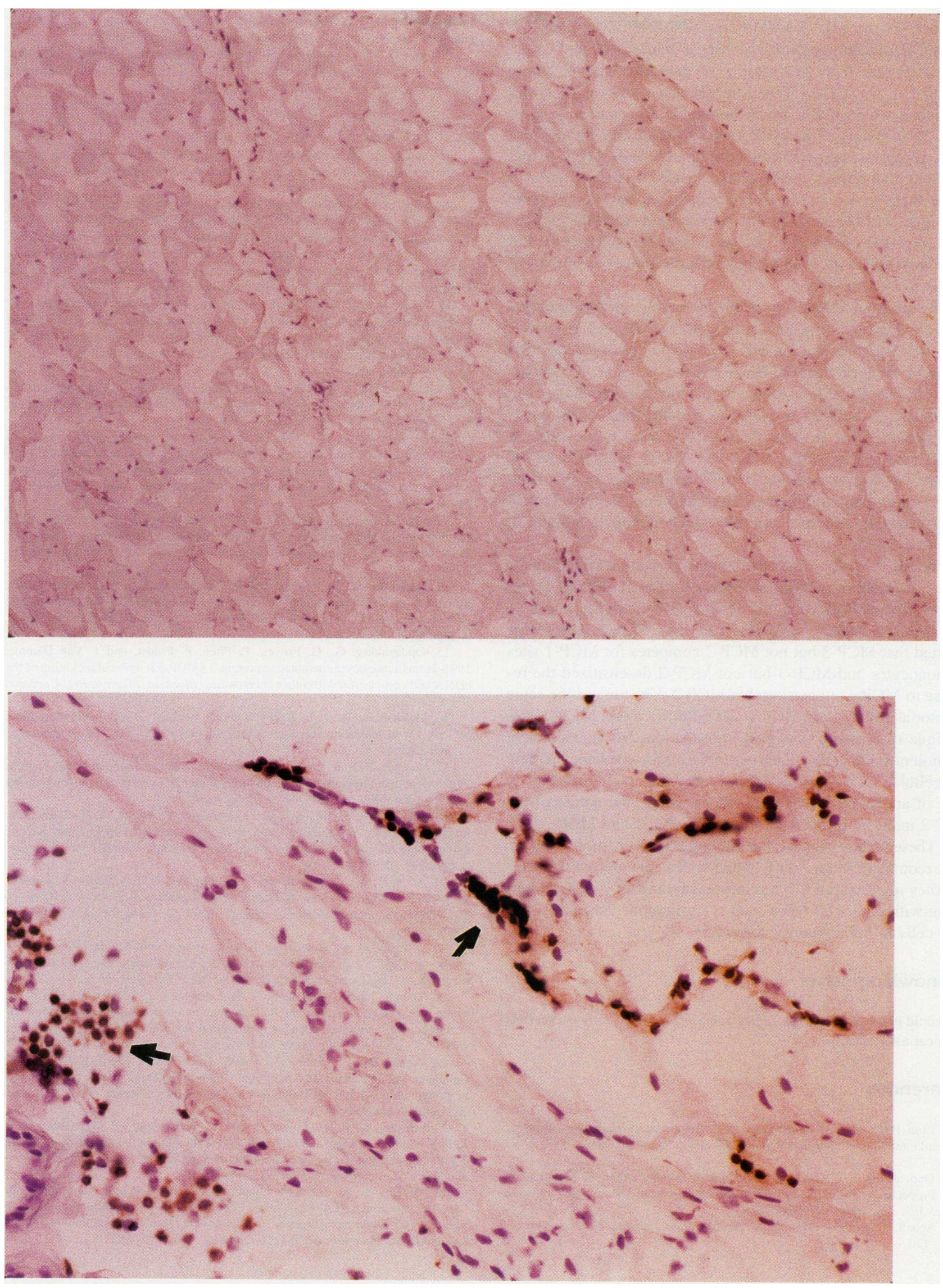
chamber system. Like RANTES and IP-10, MCP-1, -2, and -3 induced significant migratory activity in both $\mathrm{CD} 4^{+}$and $\mathrm{CD} 8^{+}$ $\mathrm{T}$ lymphocytes, with the majority of migratory activity being observed in the $\mathrm{CD}^{+}{ }^{+} \mathrm{T}$ cell subset. This lack of $\mathrm{T}$ subset preference using MCP-1 was also noted by Carr and colleagues (11). The capacity of the MCP as well as RANTES chemokines to act on resting peripheral blood human $T$ cells suggests that sufficient high affinity receptor is expressed by these $\mathrm{T}$ cells to enable them to respond to these chemokines prior to exposure to antigens or polyclonal stimulants. Consequently, the chemokines have the potential to act on antigen activated cells, but may also regulate the homing and redistribution of unstimulated $\mathrm{T}$ cells to local tissues.

The apparent redundancy of the increasing number of chemokines acting on monocytes and T cells is troubling. However, there are distinctions in the cell sources of chemokines and the timing of their production. Since MCP-1, -2, and -3, like IP10 , are secreted predominantly by activated macrophages and non-leukocytic cells in response to stimuli, these chemokines presumeably direct mononuclear cells to local tissue sites. In contrast, RANTES, MIP- $1 \alpha$ and MIP- $1 \beta$ are predominantly T lymphocyte-derived and may preferentially direct mononuclear cells towards lymphoid tissues. RANTES is constitutively produced and may therefore contribute to lymphocyte homing to lymphoid tissues.

The MCP-1, -2, and -3 terminology may not be fully appropriate since these molecules induce different biological responses although they exhibit 62 and $72 \%$ similarity in amino acid sequence relative to MCP-1 $(15,16)$. In fact, it has been reported that MCP-3 but not MCP-2 competes for MCP-1 sites on monocytes and MCP-3 but not MCP-2 desensitized the response to MCP-1 suggesting that MCP-2 does not use the same receptor as MCP-1 and MCP-3 (24). Furthermore, MCP-2 uses a unique mechanism of signal transduction that is inhibitable by cholera toxin rather than pertussis toxin, does not increase intracellular $\mathrm{Ca}^{2+}$ concentrations, and does not induce the release of arachidonic acid (24). Furthermore, the nature of the MCP-2 inducers differ from those for MCP-1 and MCP-3 (22, 25 ). These results suggest that although the $\beta$ chemokines have some redundant actions on $\mathrm{T}$ lymphocytes, they may play different roles in attracting $\mathrm{T}$ lymphocytes and monocytes in combination with other cell types such as eosinophils, basophils, and mast cells to inflammatory sites (25).

\section{Acknowledgments}

We would like to thank Kelli Taylor and Shirley Hale for their excellent technical assistance.

\section{References}

1. Taub, D. D., and J. J. Oppenheim. 1993. Review of the chemokine meeting: The third international symposium of chemotactic cytokines. Cytokine. 5(3):175178.

2. Oppenheim, J. J., C. O. C. Zachariae, N. Mukaida, and K. Matsushima. 1991. Properties of the novel proinflammatory supergene "intercrine" cytokine family. Ann. Rev. Immunol. 9:617-648.

3. Schall, T. J. 1991. Biology of the rantes/sis cytokine family. Cytokine. 3:165-170.
4. Damme, J. V. 1994. Interleukin-8 and related molecules. The Cytokine Handbook A. Thompson, editor. Academic Press, NY. p. 185-208.

5. Taub, D. D., K. Conlon, A. R. Lloyd, J. J. Oppenheim, and D. J. Kelvin. 1993. Preferential migration of activated $\mathrm{CD}^{+}$and $\mathrm{CD}^{+}{ }^{+} \mathrm{T}$ cells in response to MIP- $1 \alpha$ and MIP-1 $\beta$. Science (Wash. DC). 260:355-357.

6. Schall, T. J., K. Bacon, K. I. Toy, and D. V. Goedell. 1990. Selective attraction of monocytes and $\mathrm{T}$ lymphocytes of the memory phenotype by the cytokine RANTES. Nature (Lond.). 347:669-672.

7. Tanaka, Y., D. H. Adams, S. Hubscher, H. Hirano, U. Siebenlist, and S. Shaw. 1993. T-cell adhesion induced by proteoglycan-immobilized cytokine MIP1 $\beta$. Nature (Lond.). 361:81-84.

8. Schall, T. J., K. Bacon, R. D. R. Camp, J. W. Kaspari, and D. V. Goeddel. 1993. Human macrophage inflammatory protein- $1 \alpha$ (MIP- $1 \alpha)$ and MIP- $1 \beta$ chemokines attract distinct populations of lymphocytes. J. Exp. Med. 177:1821-1830.

9. Larsen, C. G., A. O. Anderson, E. Appella, J. J. Oppenheim, and K. Matsushima. 1989. Neutrophil activating factor (NAP-1) is also chemotactic for T lymphocytes. Science (Wash. DC). 243:1464-1468.

10. Taub, D. D., A. R. Lloyd, K. Conlon, J. M. Wang, J. R. Ortaldo, A. Harada, K. Matsushima, D. J. Kelvin, and J. J. Oppenheim. 1993. Recombinant human interferon-inducible protein 10 is a chemoattractant for human monocytes and $\mathrm{T}$ lymphocytes and promotes $\mathrm{T}$ cell adhesion to endothelial cells. J. Exp. Med. 177:1809-1815.

11. Carr, M. W., S. J. Roth, E. Luther, S. S. Rose, and T. A. Springer 1994. Monocyte chemoattractant protein 1 acts as a T-lymphocyte chemoattractant. Proc. Natl. Acad. Sci. USA. 91:3652-3656.

12. Yoshimura, T., N. Yuhki, S. K. Moore, E. Appella, M. Lerman, and E. J. Leonard. 1989. Human monocyte chemoatrractant protein-1 (MCP-1): Fulllength cDNA cloning, expression in mitogen-stimulated blood mononuclear leukocytes, and sequence similarity to mouse compentence gene JE. FEBS Lett. 244:487-495

13. Matsushima, K., C. G. Larsen, G. C. DuBois, and J. J. Oppenheim. 1989. Purification and characterization of a novel monocyte chemotactic and activating factor produced by a human myelomonocytic cell line. J. Exp. Med. 169:14851494.

14. Van Damme, J., P. Proost, J.-P. Lenaerts, and G. Opdenakker. 1992. Structural and functional identification of two human, tumor-derived monocyte chemotactic proteins (MCP-2 and MCP-3) belonging to the chemokine family. J. Exp. Med. 176:59-64.

15. Opdenakker, G., G. Froyen, P. Fiten, P. Proost, and J. Van Damme. 1993. Human monocyte chemotactic protein-3 (MCP-3): molecular cloning of the cDNA and comparison with other chemokines. Biochem. Biophys. Res. Commun. 191:535-537.

16. Matsushima, K., E. T. Baldwin, and N. Mukaida. 1992. Interleukin-8 and MCAF: Novel leukocyte recruitment and activating cytokines. Chem. Immunol. 51:236-265.

17. Kuna, P., S. R. Reddigari, D. Rucinski, J. J. Oppenheim, and A. P. Kaplan. 1992. Monocyte chemotactic and activating factor is a potent histamine-releasing factor for basophils. J. Exp. Med. 175:489-496.

18. Bischoff, S. C., M. Krieger, T. Brunner, A. Rot, V. V. Tscharner, M. Baggiolini, and C. A. Dahinden. 1993. RANTES and related chemokines activate human basophil granulocytes through different $\mathrm{G}$ protein-coupled receptors. Eur. J. Immunol. 23:761-770.

19. Alam, R., M. A. Lett-Brown, P. A. Forsythe, D. J. Anderson-Walters, C. Kenamore, C. Kormos, and J. A. Grant. 1992. Monocyte chemotactic and activating factor is a potent histamine-releasing factor for basophils. J. Clin. Invest. 89:723-728.

20. Wang, J. M., A. Hishinuma, J. J. Oppenheim, and K. Matsushima. 1993. Studies of binding and internalization of human recombinant monocyte chemotactic and activating factor (MCAF) by monocytic cells. Cytokine. 5:264-271.

21. Damme, J. V., B. Decock, J.-P. Lennerts, R. Conings, R. Bertini, A. Mantovani, and A. Billiau. 1989. Identification by sequence analysis of chemotactic factors for monocytes produced by normal and transformed cells stimulated with virus, double-stranded RNA or cytokines. Eur. J. Immunol. 19:2367-2373.

22. Damme, J. V., P. Proost, W. Put, S. Arens, J.-P. Lenaerts, R. Conings, G. Openakker, H. Heremans, and A. Billiau. 1994. Induction of monocyte chemotactic proteins MCP-1 and MCP-2 in human fibroblasts and leukocytes by cytokines and cytokine inducers. J. Immunol. 152:5495-5502.

23. Murphy, W. J., D. D. Taub, M. Anver, K. Conlon, J. J. Oppenheim, D. J. Kelvin, and D. L. Longo. 1994. Human RANTES induces the migration of human $T$ lymphocytes into the peripheral tissues of mice with severe combined immune deficiency. Eur. J. Immunol. 24:1823-1828.

24. Sozzani, S., D. Zhou, M. Locati, M. Rieppi, P. Proost, M. Magazin, N. Vita, J. V. Damme, and A. Mantovani. 1994. Receptors and transduction pathways for monocyte chemotactic protein-2 and monocyte chemotactic protein-3: similarities and differences with MCP-1. J. Immunol. 152:3615-3622. 